\title{
Mentoring and Teacher Effectiveness in Government-Aided Secondary Schools in the Acholi Sub Region in Uganda
}

\author{
John Bismarck Okumu1 ${ }^{*}$, Tom Henry Ogwang1, Wycliffe Scott Wafula ${ }^{2}$ \\ ${ }^{1}$ Faculty of Education and Humanities, Gulu University, Gulu, Uganda \\ ${ }^{2}$ School of Education and External Studies, Makerere University, Gulu, Uganda \\ Email: ‘jb.okumu@gu.ac.ug, t.hogwang@gu.ac.ug,wswafula@gmail.com
}

How to cite this paper: Okumu, J. B., Ogwang, T. H., \& Wafula, W. S. (2021). Mentoring and Teacher Effectiveness in Government-Aided Secondary Schools in the Acholi Sub Region in Uganda. Creative Education, 12, 2700-2714.

https://doi.org/10.4236/ce.2021.1211200

Received: September 18, 2021

Accepted: November 27, 2021

Published: November 30, 2021

Copyright $\odot 2021$ by author(s) and Scientific Research Publishing Inc. This work is licensed under the Creative Commons Attribution-NonCommercial International License (CC BY-NC 4.0). http://creativecommons.org/licenses/by-nc/4.0/ (c) (i) (8) Open Access

\begin{abstract}
This paper reports on a study which was conducted to investigate the relationship between mentoring and teacher effectiveness in Government-aided secondary schools in the Acholi sub-region in Uganda. The study used a descriptive, cross-sectional survey design focusing on teachers in government-aided secondary schools in the Acholi sub-region. It found that the assistance given to teachers helps build their confidence, improve their teaching, and help teachers to improve their effectiveness and efficiency in guiding learners' achievements. It concluded that helping teachers to improve their effectiveness in government-aided secondary schools builds teachers' confidence in teaching and students' learning. In this way, mentoring helps strengthen teachers' classroom practices in Government aided secondary schools. Thus, the study recommended that mentoring guidance should focus on helping teachers employ social interactions and instructional practices; feedback and clarity in teaching that have direct measurable impacts on student learning achievements.
\end{abstract}

\section{Keywords}

Mentoring, Mentors, Mentees, Teacher Effectiveness, Government-Aided Secondary School

\section{Introduction}

Mentoring is a process in which an experienced individual helps another person develop his or her goals and skills through a series of time-limited, confidential, one-on-one conversations and other learning activities (The Center for Health 
Leadership \& Practice, 2003: p. 1). Mentoring is an interactive process that helps individuals acquire teaching skills based on lesson designs, methods of delivery; stimulating interests in the subject and motivating students to learn more effectively and efficiently thus improving teacher effectiveness (Metros \& Yang, 2006).

The word mentoring also relates to the Latin word "mens" that is, pertaining to, or occurring in the mind (Simpson \& Weiner, 1989). Braimoh (2008), defines mentoring as a process where an older person with rich life experiences helps to guide a younger and inexperienced person. Mentoring was very helpful as it could guide, encourage and motivate the individuals in organizations/institutions. This process of helping teachers when well executed will lead to students' achievement in Government-aided secondary schools. The practice of apprenticeship and transferring generational knowledge, so prevalent in craft societies of past centuries, draws heavily on the concept of mentoring (Deans et al., 2006).

Altaf (2012) observes that the term "teacher effectiveness" is used broadly, to mean the collection of characteristics, competencies, and behaviours of teachers at all educational levels that enable students to reach desired learning outcomes, which may include the attainment of specific learning objectives as well as broader goals such as being able to solve problems, think critically, work collaboratively, and become effective citizens.

As a professional development tool, mentoring has direct relevance to teacher effectiveness (Nolan, 2012). As a tool for addressing social exclusion, it means that teachers need to liaise with mentors to gain inclusion in the body of professionals. Mentoring is essential as it brings about changes in pedagogical practices. Through mentoring teachers are guided, supported and taught to transform their classroom practices. This transformation improves mentees preparations, teaching quality and learning environment leading to teacher effectiveness. Mentoring transforms mentees' classroom practices compared to those who are not mentored. This is supported by Clark \& Byrnes, (2012) who explain that mentors rated that the mentoring experiences they had are more helpful as compared with those mentees who were not provided mentoring support.

Mentoring processes guide mentees to develop their talents, skills, knowledge and to change attitudes towards teaching. It is a liberating approach to teaching couched in an act of cognition not in the transfer of information. According to Center for Health Leadership \& Practice (2003), the most valued mentoring skill is giving encouragement. This includes giving your mentoring partners recognition and sincere positive verbal feedback. As mentees are guided, supported and taught, they transform the way they teach. The observations, interactions and practices they make improve teacher effectiveness. Mentees who are not mentored will continue to teach the same way they were taught in the Universities, meaning they will not be transformed into effective teachers as their classroom practices will not be improved.

Mentees who have not undergone transformation largely use transmission 
methods of teaching, which lack the $21^{\text {st }}$ Century approach (Nabwire et al., 2015). They place too much emphasis on academic learning and passing examinations at the expense of appropriate knowledge and skills needed for solving real life problems. A strong strand in the mentors' perception of their role was that of looking at themselves as learners who would also grow as a consequence of the mentoring interactions (Halai, 2018). These studies provide evidence of mentor's knowledge enhancement of how teachers learn their developing or refining skills of working collaboratively with teachers' an down development of their subject knowledge.

Helping mentees to improve their teaching process can be measured by the experience, training and qualifications of the mentors and further using the mentors' skills. Garringer \& Jucvy, (2008) note that at times, your role might include helping, your mentees with school work, and this assistance should be given in, a way that helps build their self-confidence. Although not all mentors are well trained in guiding teachers there is need to extend this assistance to all teachers. McKimm et al., (2007), note that mentoring fosters effectiveness in that it improves awareness of one's learning gaps, develops ability to give and take criticism, widens skills-based competences, develops own practice and, may accelerate professional development. However, teacher effectiveness is affected by inadequate teacher support. In the event of a mismatch occurring, it would certainly be an uncomfortable experience for both mentor and mentee because this situation would not foster teacher effectiveness. Collaboration in the development of teaching skills to bring about teacher effectiveness is now a worldwide phenomenon (Sanders, 2002).

MOES, (2012) points out that teachers are using mainly teacher-centred approaches instead of learner centred approaches and are also administering unplanned tests and assessments to measure learning achievement (UNEB, 2015). Despite the government initiatives to improve the quality of teaching through mentoring, the quality of pedagogy still remains poor. These teachers lack contemporary teaching skills, knowledge and strategies, show poor preparation, inadequate teaching quality, poor learning environment. Yet through mentoring teacher effectiveness can be transformed for better classroom practices.

McKimm et al., (2007) note that mentoring fosters effectiveness in that it improves awareness of one's learning gaps, develops ability to give and take criticism, widens skills; based competences, develops one's own practice and; may accelerate professional development. However, teacher effectiveness is affected by inadequate teacher support. In the event of a mismatch occurring, it would certainly be an uncomfortable experience for both mentor and mentee because this situation would not foster teacher effectiveness. Collaboration in the development of teaching skills to bring about teacher effectiveness is now a worldwide phenomenon (Sanders, 2002).

In the Acholi sub-region of Northern Uganda, a report from (MOES, 2004) reveals that mentoring has become an extremely popular policy for improving 
the performance of teachers. What perhaps remains a concern is that mentors have not been trained adequately in the mentoring process and seem to have negative attitudes towards mentoring in government-aided secondary schools. Teachers continue to be absent from schools and even when they are present, they do not enter classes to teach regularly, despite being timetabled to be teaching. The behaviours of the teachers indicate that mentoring is resisted in the Acholi sub-region Government-aided secondary schools, as they say, "We did mentoring before and it did not work: we do not have time and resources" (MOES, 2003). It is evident that teachers resist the mentoring process and therefore little attention is given to the mentoring process and yet it is a strategy that is acclaimed for developing the teaching skills of teachers. Perhaps teachers in the Acholi sub-region have been teaching poorly because of resistance to mentoring in Government-aided secondary schools (MOES, 2012). Teachers still have inadequate preparation of schemes of work, poor lesson plan preparation, lack of continuous assessment, scarcity of evaluative comments in lesson plans and inadequate preparation of instructional materials. Their weaknesses found in meeting these quality indicators raise deeper questions about the extent to which mentoring is a reality and meaningfully being conducted in these institutions. The study was conducted to establish the effects of mentoring on teacher effectiveness in Government-aided secondary schools in the Acholi sub-region.

Mentoring improves mentees' skills, it sets them up to enter the classroom better prepared both in terms of how to teach and what to teach (Ramma \& Bholoa, 2018). Some mentees do not feel free to interact with mentors; they fear that their weaknesses will be exposed. Driscoll et al., (2009) in their research found that the mentoring assists mentees to discover their own voices and scholarly approach and to understand themselves and establish supportive relationship. Clark \& Byrnes (2012) note that mentors rated that the mentoring experiences they had are more helpful as compared with those mentees who were not provided mentoring support.

According to Doney (2013), Gibbs \& Miller (2014), Greenfield (2015) and Hong (2012) mentoring and additional support practices help "develop mentees" professional identities in the form of confidence, self-efficacy, belief and resilience. Achinstein \& Davis (2014) found that mentees increase their effectiveness when they are helped with strong instructional guidance rather than by learning on their own. While Danielson (2000) found that mentoring helps mentees face their new challenges. Similarly; Power and Starr-Glass (2005) note that mentoring is prominent in education systems throughout the world. Hudson and Hudson (2007) found that mentors in professional experience settings are well positioned to assist mentees in improving their effectiveness. However, not all mentors have the same capacity to help mentees improve on their teaching effectiveness. Cain (2009), points out that mentoring is effective in developing mentees' teaching skills, although it often fails to live up to ideals.

\section{Transformative theory}

There are many theories in mentoring which include Constructivism, So- 
cio-Cognitive Theory, Socio-Cultural Theory and Transformative theory. This study was guided by transformative theory because Transformative theory can help us understand in more detail the learning processes and changes in meaning perspectives that must take place (Percy, 2005). Transformative theory is a new and evolving theory resulting from the research and work of scholars: Daloz (1986).

It has been selected because it is a theory of existence that views people as subjects not objects. People are constantly reflecting and acting on the transformation of their world so that it can become a more equitable place for all to live (Daloz, 1986). The goal of transformational theory is social transformation by explaining reality, where the oppressed develop critical consciousness. Mentoring helps mentors (Senior teachers), guide and encourage mentees (Junior teachers) to become more effective in the teaching process. Transformational theory is the centrality of critical reflection with the purpose of rediscovering power and helping mentees to develop an awareness of the urgency to transform society and their own reality.

Mentoring guides mentees to develop their talent, skills, knowledge and to change attitudes towards teaching. It is a liberating approach to teaching couched in an act of cognition not in the transfer of information. Mentoring makes mentees to think critically, creatively and become reasonable, reflective practitioners. It is a problem posing and dialogical methodology. Through the mentoring process mentees are supported on the job to gain more courage and continuous learning to perfect their skills in teaching and become more effective. It is a horizontal mentee-mentor relationship where the mentors work as political agents and on an equal footing with mentees. The concept of transformation refers to change. Some transformational theorists share the humanistic view that learners are capable of changing and free to act on the world. Daloz (1986) focuses on the impact education has on the diversity of adult learners. Adult learning theories have been identified as the dominant theoretical framework behind mentoring because it makes a mentees' experience meaningful (Knowles 1984).

Daloz's (1986) model locates mentees growth as a teacher within a context of support and challenge and identifies that development can help the mentor guide, challenge, support and illuminate the way ahead. The model is based upon the view that where support is low, there is little opportunity for any challenge to occur and the mentee may withdraw from the mentoring relationship. Conversely, if support is high, new knowledge and images of teaching become possible for mentees. In this case, Daloz's (1986) concept of mentoring is not only concerned with developing cognitive competence but more importantly in fostering the personal growth of a mentee to be effective in a teaching and learning environment. Personal development is facilitated by the relationship between mentors and mentees.

Through a mentoring relationship consisting primarily of one-to-one interac- 
tions, mentee and mentor construct meaning and make sense of their respective world (Prickel, 2013). Mentoring as a professional tool thus improves teacher effectiveness in that inexperienced teachers (mentees) are paired up with experienced teachers (mentors). Therefore, mentoring has been accepted as an effective method of preparing the mentees to enter the teaching profession (Sundli, 2007).

\section{Methodology}

The study used a mixed method, cross-sectional survey through which the researcher collected data on mentoring and teacher effectiveness in Government -aided Secondary schools from (Creswell, 2012) varied categories of the population. The data was triangulated, all of which the research team used throughout the research: multiple research methods (mixed method), multiple sources within one method, multiple analysts, and multiple theories and perspectives. The qualitative method was used to build a complex, holistic picture, formed with words, reputing the detailed views of information and conducted in a natural setting (Creswell, 2009; Koul, 1997) while the quantitative method was used because it is cheap and can be completed within time required to enable a large quantity of relevant data to be amassed and subjected to statistical analysis techniques for greater representation (Punch, 2006).

The study focused on Government-aided secondary schools in the eight districts of the Acholi sub-region of which Gulu district has9, Omoro 6, Kitgum 8,Pader 7, Agago 6, Amuru 4, Nwoya 4 and Lamwo 4 schools respectively; adding up to 48 Government-aided secondary schools. Acholi sub-region was chosen because it is strategically located and experienced insurgency for many years which interrupted teacher support (mentoring) for effective teaching and learning. Secondary schools that have both ordinary and advanced levels of education were selected. The target population included Head teachers, Deputy Head teachers, Directors of studies and teachers of Government-aided secondary schools in the Acholi Sub-region as follows:

14 Head teachers, 14 Deputy Head teachers, 14 Directors of studies, and 336 teachers were targeted because they have different perceptions and ideas about mentoring and its impact on teacher effectiveness in teaching which may lead to variations in teacher effectiveness. Government-aided secondary schools and teachers in the Acholi sub-region were sampled using stratified random sampling technique. The Head teachers, Deputy Head teachers and Directors of studies in the Government-aided secondary schools were sampled using purposive sampling. The teachers from the Government aided secondary schools were selected using simple random sampling technique where 8 teachers comprising of 4 males and 4 females were selected in each school making a total of 336 teachers. Following the above, 14 Head teachers, 14 Deputy Head teachers and 14 Director of studies were selected using purposive sampling technique making a total of 42 . The total samples of all respondents was 378 as shown in Table 1 . 
Table 1. Showing sample frame for the target population.

\begin{tabular}{ccccc}
\hline $\begin{array}{c}\text { Categories of } \\
\text { respondents }\end{array}$ & $\begin{array}{c}\text { Target } \\
\text { population }\end{array}$ & Samples & Percentages & Sampling techniques \\
\hline Head teachers & 48 & 14 & $4 \%$ & Purposive \\
Deputy head teachers & 48 & 14 & $4 \%$ & Purposive \\
Directors of studies & 48 & 14 & $4 \%$ & Purposive \\
Teachers & 966 & 336 & $88 \%$ & Stratified random sampling \\
Total & 1,110 & 378 & $100 \%$ & \\
\hline
\end{tabular}

Both primary and secondary data was collected. The researcher used questionnaires for teachers, open-ended interview for Head-teachers, Deputy head-teachers and Directors of studies and documentary analysis to collect the data. Quality control was ensured through determining validity, reliability and extraneous variables. Data analysis was aided by the Statistical Package of Social sciences (SPSS) version 18.0 for both inferential and descriptive statistics and the analysis was done in two phases. In phases one, Chi-square test descriptive analysis was used as guided by the research hypotheses. While in-phase two, the descriptive response from the head-teachers, deputy-head teachers-(academic)-directors of studies and teachers were organized according to the themes identified from research questions and analyzed using a qualitative data analysis software method called "customs table".

The ethical considerations were addressed by the researcher who obtained a letter of introduction from Gulu University, Faculty of Education and Humanities and Gulu University Research Ethics Committee to introduce him to the Resident District Commissioners, District Education Officers and Head teachers of the selected Government-aided secondary Schools in the Acholi sub-region. Confidentiality and anonymity were addressed by keeping especially personal information or sensitive issues confidential and anonymous so that readers may not be able to discover the identity of the respondents. Personal life, attitudes and feelings were kept private and protected in a lockable place and were used by researchers only.

\section{Findings}

Mentoring improves teacher effectiveness in government aided secondary schools in the Acholi sub-region

The teachers from Government-aided secondary schools in the Acholi sub-region were asked whether mentoring given to them improves teacher effectiveness. The findings indicated that help given to mentees has significant positive effects on teacher effectiveness as shown in Table 2.

As presented in Table 2, teachers were assessed on whether help given to them improves their effectiveness. $58.1 \%$ of teachers strongly agreed that the assistance given to them helps build their confidence in teaching. Teachers are 
Table 2. Analysis of mentoring helps to improve teacher effectiveness.

\begin{tabular}{|c|c|c|c|c|c|}
\hline Statements of inquiry & SA (\%) & $\mathrm{A}(\%)$ & NS (\%) & $\mathrm{DA}(\%)$ & SDA (\%) \\
\hline The assistance given to teachers help build their confidence in teaching & 58.1 & 19.4 & 8.1 & 8.1 & 6.5 \\
\hline Mentoring guidance helps improve teachers' teaching skills & 24.5 & 49.7 & 9.7 & 8.7 & 7.4 \\
\hline $\begin{array}{l}\text { Mentoring helps teachers to enter the classroom better prepared } \\
\text { both in terms of how to teach and what to teach }\end{array}$ & 32.3 & 41.9 & 12.9 & 9.7 & 3.2 \\
\hline $\begin{array}{l}\text { Mentoring experiences are more helpful as compared with teachers } \\
\text { who were not provided mentoring supports. }\end{array}$ & 35.5 & 48.4 & 16.1 & 0.0 & 0.0 \\
\hline $\begin{array}{l}\text { Teachers increase their effectiveness when they are helped } \\
\text { with strong instructional guidance }\end{array}$ & 38.7 & 51.6 & 6.5 & 3.2 & 0.0 \\
\hline Mentoring is effective in developing trainees teaching skills & 33.9 & 44.2 & 20.3 & 1.0 & 0.6 \\
\hline $\begin{array}{l}\text { Mentorships are valuable in helping mentees advance } \\
\text { in their careers and build self-confidence }\end{array}$ & 31.0 & 40.0 & 13.2 & 9.4 & 6.5 \\
\hline Mentoring helps new teachers face their new challenges. & 32.3 & 45.2 & 12.9 & 6.5 & 3.2 \\
\hline AVG & 35.8 & 42.5 & 12.5 & 5.8 & 3.4 \\
\hline
\end{tabular}

Source: Primary data, 2020.

guided by mentors after observing their teaching process thus, helping teachers to improve their effectiveness. $51.6 \%$ of teachers agreed that teachers increase their effectiveness when they are helped with strong instructional guidance. $49.7 \%$ of teachers also agreed that mentoring guidance helps them improve their skills of teaching. This implies that the kind of help given to teachers improve teacher effectiveness in Government-aided secondary schools in Acholi sub-region. Therefore, the null hypothesis that there is no significant effect on teachers' effectiveness in Government -aided secondary schools was rejected because the chi-square calculated value was 0.58 and this is higher than $P$ value of 0.01 .

Using interviews, DoS, D/Hrs and $\mathrm{H} /$ trs from Government -aided secondary schools from the Acholi sub-region were interviewed each individually. The findings from this sample group indicated that $80 \%$ of respondents agreed with the teachers' responses. The respondents reported that helping teachers can improve on teacher's effectiveness. For instance, one of the DoS4 reported thus:

by being close to the mentees and sharing ideas, knowledge, talking about their welfare, by monitoring their work, discussing with them their areas of strengths and weaknesses help mentees to improve their effectiveness.

There was general consensus among Deputy Head teachers that helping teachers can improve teacher effectiveness. One Deputy Head teacher asserted that:

"by discussing with mentees, encouraging proper preparations, ensuring good class supervision, and one-on-one discussion helps mentees to improve on teacher effectiveness". 
The Head teachers in turn agreed that helping teachers can improve their effectiveness. Nine Head teachers asserted that teachers can be helped through strategies such as

"motivation", "giving them what they desire", "delegating duties", "reviewing their schemes of work and guide them", "evaluate their work", "giving feedback," and "encourage their creativity".

One Head teacher observed that teachers can improve their effectiveness;

by using team teaching approach, working together with mentors through collaboration enhances mentees knowledge of instructional strategies, promoting competency and confidence in their profession

The document analysis revealed that teachers are helped in their teaching process by, the DOS, D/Htrs and Htrs who check and endorse their' schemes of work and lesson plans. They also make comments on teachers' preparation books.

This implies that the majority of the DoS, D/Hrs and Htrs agree on ways of helping mentees improve their effectiveness in teaching, (20\%) of the DoS, (10\%) of the D/Htrs and (20\%) of $\mathrm{H} /$ trs cited departmental meetings, cooperation, being close to the mentees and demonstrating various teaching approaches, as ways of helping mentees to improve their effectiveness in teaching.

\section{Discussion}

This study investigated the effects of mentoring and teacher effectiveness in Government aided secondary schools in the Acholi sub-region. It demonstrated that several key factors are important in the mentorship process; it builds teachers confidence in teaching, it helps with strong instructional guidance. Based on the socio-cognitive theory (Bandura, 1977) Socio-cultural theory, (Vygotsky, 1978) and Adults theory (Knowles, 1984), teachers require to learn from each other by seeing and modeling. Teachers also learn from each other through interaction so that they have working skills. They are the light of a nation in that through their teaching; they prepare learners wholly who later help in nation's economic development. Secondary schools therefore need resourceful, innovative and creative teachers that can fulfill the interests and demands of the learners and society as a whole.

The findings explain why helping a teacher has effects on teacher effectiveness in Government aided secondary schools in the Acholi sub-region. The mentors in these schools have been found to be close to the mentees, share ideas with the mentees, talk about their welfare, monitor the mentees work and then discuss with them their areas of strengths and weaknesses (Bandura, 1977; Vygotsky, 1978; Knowles, 1984). This concurs with what these scholars postulated as a result, teachers become effective in teaching in secondary schools. Teachers can improve their effectiveness through sharing experiences with mentors, giving feedback on their work, these help mentees to improve their teaching effective- 
ness in government aided secondary schools in the Acholi sub-region.

The findings revealed that the assistance mentors give to teachers help them build confidence in teaching. The teachers' responses occurred with the mentors' where $80 \%$ indicated that there is Government-aided secondary schools showed that there is significant positive effect of assistance given to teachers for instance by discussing with mentees, encouraging proper preparations, ensuring good classroom supervision, and one-on-one discussion which improves teacher effectiveness. This confirms Mendenhall, et al., (2015) view that assistance given to teachers makes positive changes to their classroom practices, creates a safer learning environment, improves their relationships with their mentors, bolsters their confidence; and motivates them in teaching. Similarly, (Sarma et al., 2013) found that training helps teachers to be comfortable in conducting classes, and in explaining sensitive issues. They affirmed that, as they learnt from training, they could prepare classspecific lessons.

Several scholars (Nguyen, 2009; Ofsted, 2004; Bandura, 1986: p. 25; Bandura, 1994; Genevieve, 2017); Kawaah, 2018; Laurillard, 2013) all agreed that the assistance given to teachers helps them build confidence in teaching. However, this contradicts the finding by Kawaah (2018) that assistance had very little exposure to real classroom practices in the course of their training, a situation which eventually made them ineffective teachers in Ghana. However, the assistance given to teachers helps them build confidence in teaching. This is because such help enhances mentees' skills, knowledge of content, and pedagogical knowledge in classroom practices. If the mentor is enthusiastic and energetic, their mentees will be active as well.

The assistance also makes mentees in Government-aided secondary schools friendly, pleasant and enthusiastic. They gain confidence in classroom practices; for example, they will confidently prepare their lesson plans and schemes of work, present the lesson and carry out assessment with ease. When mentee help is visualized from the Uganda perspective, the situation is not the same as pointed by Munir and Amin (2018) who argues that one of the bottlenecks constraining the quality of classroom practice is inadequate assistance and inadequate experiences among mentors. This results in low motivation, incompetence and loss of trust among mentees. The researcher found that, help given to mentees enhances their teaching competencies and confidence in classroom practices for example, they learn to communicate effectively, prepare adequate instructional materials and present content systematically. But according to organizational behaviour theories, mentors motivational level determines the level of their performance. School mentors could use various strategies to motivate mentees for example through support supervision, providing quality feedback, sending them for training, praising and rewarding good performance and encouraging and supporting weak performance.

Mentees may be given professional development opportunities that can act as a supportive guide for improvement. As pointed by Cronin (2019), who argues 
that the mentoring process exposes new ideas and revelatory ways of thinking or problem solving. This can have long lasting effects on both people in the partnership, encouraging innovation. Mentees are often aware of their weakness but do not know how to fix them, which leads to a lack of confidence. Creating a culture that hinges around peer support and collaboration and providing time and tools for mentees to develop is great in building confidence and stronger culture as a whole. Mentors' level of confidence in their abilities can be highly enhanced by past experience or current school culture.

Mentees with strong sense of confidence also tend to be better planners, more resilient through failure and more open-minded and supportive. (Herbert-Smith, 2019) argued that interestingly, seeing students grow and working in a collaborative environment can boost a teacher's belief in their ability and improve performance. Research also suggests that teachers with a strong sense of self-efficacy tend to be better planners, more resilient through failure, and more open-minded and supportive with students. However, in Government-aided secondary school, it was found that the mentoring process is not adequately handled, because mentors are not trained to build confidence in mentees as noted by (Herbert-Smith, 2019) that bad classroom experiences or negative work environment can quickly diminish a mentee's confidence. Mentors need to assist mentees to build confidence in their work so that they change their teaching skills.

\section{Conclusion}

In this paper, the researchers investigated mentoring and teacher effectiveness in general and observed that teachers are the light of a nation in that through teaching; they prepare learners who later help in a nation's economic development. Secondary schools therefore need resourceful, innovative and creative teachers that can fulfill the interests and demands of the learners and society as a whole.

Mentoring has enormous potential to bring about learning, personal growth and development for professional teachers. This study confirms that helping teachers to improve their classroom practices is very essential and builds their' confidence in teaching. Teachers increase their effectiveness when they are helped with strong instructional guidance in this way, it improves their skills of teaching.

The school mentors (DoS, D/Htrs and Htrs) from Government-aided secondary schools in the Acholi sub region positively acknowledged that helping teachers to improve teaching process is equally important. This explains why helping teachers has significant effects on their effectiveness in Government-aided secondary schools in the Acholi sub-region.

The mentors in these schools are close to the mentees, share ideas with them, talk about their welfare, monitor the mentees work and then discuss with them their areas of strengths and weaknesses. However, one of the bottlenecks constraining the quality classroom practice is inadequate assistance and inadequate 
experiences among mentors. These result in low motivation and incompetence, loss of trust among mentees. Helping mentees improve their skills sets them up to enter the classroom better prepared both in terms of how to teach and what to teach. The research results showed that mentors in Government-aided secondary schools do not adequately help guide mentees to improve on teacher effectiveness. And yet helping mentees can result in teacher (mentees) being creative, resourceful, confident and active in teaching.

\section{Recommendations}

The goal of mentoring is to guide teachers improve their teaching practices in Government-aided secondary schools. Mentoring guidance should focus on helping teachers employ "high-yielding" instructional practices; feedback and clarity in teaching that have direct measurable impacts on student learning. For example, mentoring teams should be formed in Government-aided secondary schools to help teachers that may need individual help in specific areas of teaching process Through routine mentoring, the school mentors should identify teachers facing difficulties in teaching such as content mastery, use of learners' experiences, use of instructional materials and choosing contemporary teaching methods in order to help the macquire more skills, build their confidence and encourage team teaching among teachers.

Government aided secondary schools should include mentoring programme in the school timetable. The mentors and mentees should have schedules that are followed strictly to help improve teacher effectiveness.

The Ministry of Education and Sports should include mentoring programmes in the teacher education curriculum to equip teachers with mentoring skills in secondary schools in Uganda.

\section{Acknowledgements}

I would like to thank God the Almighty for the gift of life and favour that enabled me complete this piece of work. Secondly, I am thankful for the support and guidance of Professor Elizabeth AumaOpiyo and Dr. Echodu Richard. You have helped me understand the value of research and process done the right way. I am both humbled and inspired by the opportunity that Gulu University provided for me. Thank you for your considerations. I also wish to thank DANIDA through Building Stronger University Project for giving me financial support for research work. I would like to thank THRIVE (Training Health Researchers into Vocational Excellence in East Africa) for providing a platform for continuous support through organizing workshops in the area of scholarly writing thank you so much. I am grateful to the secondary school teachers, who participated in the study for the invaluable data they contributed to this study. Thank you so much for your effort.

\section{Conflicts of Interest}

The authors declare no conflicts of interest regarding the publication of this paper. 


\section{References}

Achinstein, B., \& Davis, E. (2014). The Subject of Mentoring: Towards a Knowledge and Practice Base for Content-Focused Mentoring of New Teachers. Mentoring \& Tutoring: Partnership in Learning, 22, 104-126. https://doi.org/10.1080/13611267.2014.902560

Altaf, D. (2012). Teacher Effectiveness and Competency, Concept, Principles and Criteria.

Bandura, A. (1986). Social Foundations of Thought and Action: A Social Cognitive Theory. Prentice-Hall.

Bandura, A. (1994). Self-Efficacy. In Encyclopaedia of Human Behaviour. Academic Press.

Bandura, A. J. (1977). Social Learning Theory. General Learning Press.

Braimoh, D. (2008). Lifelong Learning through Mentoring Process and Its Operational Dimensions in Society Turkish. Turkish Online Journal of Distance Education, 9, 16-25.

Cain, T. (2009). Mentoring Trainee Teachers: How Can Mentors Use Research? Crisp Publications. https://doi.org/10.1080/13611260802233498

Clark, S. K., \& Byrnes, D. (2012). Through the Eyes of the Novice Teacher: Perceptions of Mentoring Support. Teacher Development, 16, 43-54. https://doi.org/10.1080/13664530.2012.666935

Creswell, J. W. (2009). Research Design Qualitative, Quantitative, and Mixed Methods Approaches (3rd ed.). CA Sage Publication.

Creswell, J. W. (2012). Educational Research, Planning, Conducting and Evaluating Quantative and Qualitative Research (4th ed.). MA Pearson.

Cronin, N. (2019). The Power and Benefits of Mentoring.

Daloz, L. (1986). Effective Teaching and Mentoring: Realizing the Transformational Power of Adult Learning Experiences. Josey-Bass Publishers.

Danielson, C. (2000). Enhancing Professional Practice: A Framework for Teaching Title. ASCD. https://www.Ascd.Org

Deans, F. et al. (2006). Coaching and Mentoring for Leadership Development in Civil Society.

Doney, P. P. (2013). Fostering Resilience: A Necessary Skill for Teacher Retention. Journal of Science Teacher Education, 24, 645-664. https://doi.org/10.1007/s10972-012-9324-x

Driscoll, L. G. et al. (2009). Navigating the Lonely Sea: Peer Mentoring and Collaboration among Aspiring Women Scholars. Mentoring \& Tutoring: Partnership in Learning, 17, 5-21. https://doi.org/10.1080/13611260802699532

Garringer, M., \& Jucvy, L. (2008). Building Relationships: A Guide for New Mentors. Hamilton Institute, George Washington University.

Genevieve, A. (2017). The Role of Teaching Practice in Teacher Education Programmes: Designing Framework for Best Practice. Global Journal of Educational Research, 16, 101. https://doi.org/10.4314/gjedr.v16i2.4

Gibbs, S., \& Miller, A. (2014). Teachers' Resilience and Wellbeing: A Role for Educational Psychology. Teachers and Teaching, 20, 609-621.

https://doi.org/10.1080/13540602.2013.844408

Greenfield, B. (2015). How Can Teacher Resilience Be Protected and Promoted? Educational \& Child Psychology, 32, 52-68.

Halai, A. (2018). Mentoring In-Service Teachers: Issues of Role Diversity. Teaching and 
Teacher Education, 22, 700-710. https://www.elsevier.com/locate/tate https://doi.org/10.1016/j.tate.2006.03.007

Herbert-Smith, K. (2019). Teacher Confidence (Efficacy): Why Does It Matter and How Can SLT Increase It?

Hong, J. (2012). Why Do Some Beginning Teachers Leave the School, and Other Stay? Understanding Teacher Resilience through Psychological Lenses. Teachers and Teaching, 18, 417-440. https://doi.org/10.1080/13540602.2012.696044

Hudson, P., \& Hudson, S. (2007). Preservice Teachers' Perceptions of Their Mentoring in Primary Mathematics Teaching. In K. Milton, H. Reeves, \& T, Spencer (Eds.), Mathematics: Essential for Learning, Essential for Life: Proceedings of the 21st Biennial Conference of the Australian Association of Mathematics Teachers (pp. 163-172). The Australian Association of Mathematics Teachers.

Kawaah, C. Y. (2018). Entry Characteristics, Academic Achievement and Teaching Practices: A Comparative Study of Two Categories of Newly Qualified Teachers in Basic Schools in Ghana. Cogent Education, 5, Article ID: 1561144.

https://doi.org/10.1080/2331186X.2018.1561144

Knowles, M. S. (1984). Andragogy in Action. Applying Modern Principles of Adult Education. Jossey Bass.

Koul, L. (1997). Methodology of Educational Research. Vikas Publishing House PVT Limited.

Laurillard, D. (2013). Using Technology to Develop Teachers as Designers of TEL: Evaluating the Learning Design. British Journal of Technology, 49, 1044-1054. https://doi.org/10.1111/bjet.12697

McKimm, J., Hatter, M., \& Jollie, C. (2007). Mentoring: Theory and Practice.

Mendenhall et al. (2015). Quality Education for Refugees in Kenya: Pedagogy in Urban Nairobi and Kakuma Refugee Camp Settings. Journal on Education in Emergencies, 1, 92-130.

Metros, S. E., \& Yang, C. (2006). The Importance of Mentors. In Cultivating Careers: Professional Development for Campus IT. Educause.

MOES (2003). Teacher Effectiveness. Mentors Training Guide. Government Printer.

MOES (2004). Teacher Effectiveness: Mentors Training Guide. Government Printers.

MOES (2012). Annual Report of the Directorate of Education Standards: Enhancing Skills Development.

Munir, F., \& Amin, M. (2018). Classroom Practices of Mentees and Mentoring Challenges in the Execution of Continuous Professional Development Framework. Bulletin of Education and Research, 40, 163-178.

Nabwire, K., Terrie, O. et al. (2015). Teacher Preparation Practices in Kenya and the 21st Century Learning: A Moral Obligation. Journal of Education and Practice, 6, 1-8.

Nguyen, H. T. (2009). An Inquiry-Based Practicum Model: What Knowledge, Practices, and Relationships Typify Empowering Teaching and Learning Experiences for Student Teachers, Cooperating Teachers and College Supervision. Teaching and Teacher Education, 25, 655-662. https://doi.org/10.1016/j.tate.2008.10.001

Nolan, A. (2012). Professional Mentoring.

Ofsted (2004). Framework for the Inspection of Initial Teacher Training of Further Education Teachers HMI 2274. HMI.

Percy, R. (2005). The Contribution of Transformative Learning Theory to the Practice of Participatory Research and Extension: Theoretical Reflections. Agriculture and Human 
Values, 22, 127-136. https://doi.org/10.1007/s10460-004-8273-1

Prickel, D. (2013). The Influence of New and Emerging Theories on Teaching Practices. School of Education, Oregon State University.

Punch, K. (2006). Developing Effective Research Proposals. Sage.

Ramm, Y., \& Bholoa, A. (2018). Helping Teachers Get Better at "How" to Teach as Well as "What" to Teach. Mauritius Institute of Education.

Sanders (2002). What Do U.K. Schools Think Makes a Good Mathematics Teacher? Educational Studies, 28, 181-191. https://doi.org/10.1080/03055690220124605

Sarma, H. et al. (2013). Impact of Training of Teachers on Their Ability, Skills, and Confidence to Teach HIV/AIDS in Classroom: A Qualitative Assessment. BMC Public Health, 13, Article No. 990. https://doi.org/10.1186/1471-2458-13-990

Simpson, E. S. C., \& Weiner, J. A. (1989). The Oxford Encyclopaedic English Dictionary. Clarendon Press.

Starr-Glass, D. (2005). From Teaching to Mentoring: Principles and Practice, Dialogue and Life in Adult Education. Journal of Transformative Education, 3, 185-189. https://doi.org/10.1177/1541344604273425

Sundli, L. (2007). Mentoring-A New Mantra for Education? Teaching and Teacher Education, 23, 201-214. https://doi.org/10.1016/j.tate.2006.04.016

The Center for Health Leadership \& Practice (2003). Mentoring Guide: A Guide for Mentors. Ethics in Science and Engineering National Clearinghouse.

UNEB (2015). The Achievement of S2 Students and Teachers in English Language, Mathematics and Biology.

Vygotsky, L. (1978). Mind in Society: The Development of Higher Psychological Processes. Harvard University Press. 